\title{
Dynamic ultra high speed Scheimpflug imaging for assessing corneal biomechanical properties
}

\author{
Avaliação Dinâmica com fotografia de Scheimpflug de alta \\ velocidade para avaliar as propriedades biomecânicas da córnea
}

Renato Ambrósio Jr ${ }^{1,2,3}$, Isaac Ramos ${ }^{1,2}$, Allan Luz ${ }^{2,3}$, Fernando Correa Faria',2, Andreas Steinmueller ${ }^{4}$, Matthias Krug ${ }^{4}$, Michael W. Belin ${ }^{5}$, Cynthia Jane Roberts ${ }^{6}$

\begin{abstract}
Objective: To describe a novel technique for clinical characterization of corneal biomechanics using non-invasive dynamic imaging. Methods: Corneal deformation response during non contact tonometry (NCT) is monitored by ultra-high-speed (UHS) photography. The Oculus Corvis ST (Scheimpflug Technology; Wetzlar, Germany) has a UHS Scheimpflug camera, taking over 4,300 frames per second and of a single $8 \mathrm{~mm}$ horizontal slit, for monitoring corneal deformation response to NCT. The metered collimated air pulse or puff has a symmetrical configuration and fixed maximal internal pump pressure of $25 \mathrm{kPa}$. The bidirectional movement of the cornea in response to the air puff is monitored. Results: Measurement time is $30 \mathrm{~ms}$, with 140 frames acquired. Advanced algorithms for edge detection of the front and back corneal contours are applied for every frame. IOP is calculated based on the first applanation moment. Deformation amplitude (DA) is determined as the highest displacement of the apex in the highest concavity (HC) moment. Applanation length $(A L)$ and corneal velocity $(\mathrm{CVel})$ are recorded during ingoing and outgoing phases. Conclusion: Corneal deformation can be monitored during non contact tonometry. The parameters generated provide clinical in vivo characterization of corneal biomechanical properties in two dimensions, which is relevant for different applications in Ophthalmology.
\end{abstract}

Keywords: Biomechanics; Cornea/physiology; Corneal topography/methods; Tonometry, ocular/methods

\section{RESUMO}

Objetivo: Descrever uma nova técnica para caracterização clínica das propriedades biomecânicas da córnea, usando sistema de imagem dinâmica não invasivo. Métodos: A resposta de deformação da córnea é monitorada durante tonometria de não contato com fotografia de Scheimpflug de altíssima velocidade. O Oculus Corvis ST (Scheimpflug Technology; Wetzlar, Germany) apresenta uma câmera UHS Scheimpflug que adquire mais que 4.300 fotos por segundo com cobertura de $8 \mathrm{~mm}$ horizontais para monitorar a resposta de deformação durante a tonometria de não contato por sopro de ar. O pulso de ar é muito bem controlado, apresentando uma configuração simétrica em sua pressão, com máxima pressão da bomba fixa de $25 \mathrm{kPa}$. O movimento bidirecional da córnea em resposta ao jato de ar é monitorado. Resultados: A medida dura $30 \mathrm{~ms}$, com 140 fotos adquiridas. Algorítmos avançados identificam os limites anterior e posterior da córnea em cada imagem. A pressão intraocular (PIO) é calculada com base no primeiro momento de aplanação. A amplitude de deformação é determinada pelo maior deslocamento do ápice, durante o momento de maior concavidade. A extensão da aplanação e velocidade da córnea são medidos nas fases de entrada e saída. Conclusão: A deformação da córnea durante a tonometria de sopro por pulso de ar pode ser monitorada em detalhe com sistema de fotografia de altíssima velocidade. Os parâmetros gerados possibilitam caracterização clínica das propriedades biomecâmicas da córnea em duas dimensões. Tais achados têm relavância para diversas áreas da Oftalmologia.

Descritores: Biomecânica; Córnea/fisiologia; Topografia da córnea/métodos; Tanometria ocular/métodos

'Instituto de Olhos Renato Ambrósio - Rio de Janeiro (RJ), Brazil;

2Rio de Janeiro Corneal Tomography and Biomechanics Study Group - Rio de Janeiro (RJ), Brazil;

${ }^{3}$ Department of Ophthalmology, il;

${ }^{4}$ Oculus GmbH - Wetzlar, Germany;

${ }^{5}$ Ophthalmology, University of Arizona - Tucson, AZ, USA;

${ }^{6}$ Ophthalmology, Department of Biomedical Engineering, The Ohio State University - Columbus, OH, USA.

Financial Disclosure(s): Mr. Steinmueller, Mr. Krug are employee of Oculus; Dr. Ambrósio, Dr. Belin and Dr. Roberts are consultants for Oculus

Recebido para publicação em: 11/4/2012 - Aceito para publicação em: 3/12/2012

Rev Bras Oftalmol. 2013; 72 (2): 99-102 


\section{INTRODUCTION}

$\mathbf{F}$ rom central keratometry to corneal topography (front surface curvature maps), then into 3-D corneal tomography systems, there was a tremendous evolution on the diagnostic methods for characterizing corneal shape $\mathrm{e}^{(1,2)}$. Biological properties, such as wound healing response and biomechanics, are essential for determining and maintaining corneal transparency, as well as geometrical and optical properties $^{(3)}$. Corneal biomechanical behavior is well known to influence the development of ectatic diseases ${ }^{(4)}$, and the results of surgery ${ }^{(5)}$. Also, corneal properties influence intraocular pressure measurements ${ }^{(6)}$, and also may be an independent risk factor for glaucomatous neuropathy ${ }^{(7-9)}$.

The assessment of corneal biomechanical properties has been limited to laboratory in vitro studies ${ }^{(4,10)}$, and to virtual mathematical corneal finite element models ${ }^{(611,12)}$. The Ocular Response Analyzer (ORA, Reichert Inc., Depew, NY), a modified non-contact tonometer (NCT) designed to provide a more accurate measurement of IOP through the understanding of compensation for corneal properties, was the first clinical tool for assessing in vivo biomechanical properties of the cornea ${ }^{(13)}$. Other nondestructive methodologies have been described, including radial shearing speckle pattern interferometry ${ }^{(14,15)}$, Brillouin optical microscopy ${ }^{(16)}$, OCT (ocular coherence tomography)(17), and other forms of dynamic corneal imaging ${ }^{(18,19)}$.

We present the Corvis ST (Scheimpflug Technology), a new NCT system integrated with an ultra-high-speed (UHS) Scheimpflug camera that was recently introduced by Oculus (Wetzlar, Germany).

\section{Methods}

The instrument has an ergonomic design (Figure 1), with adjustable head console and chin rest. The patient is comfortably positioned with proper placement of the chin and forehead. The patient is asked to focus at the central red LED (Light Emitting Diodes). A frontal view camera is mounted with a keratometertype projection system for focusing and aligning the corneal apex. The exam is programmed for automatic release when alignment is achieved with the first Purkinje reflex of the cornea. Manual release is also possible.

The UHS Scheimpflug camera takes over 4,300 frames per second to monitor corneal response to a metered collimated air puff with fixed profile that has symmetrical configuration and fixed maximal internal pump pressure of $25 \mathrm{kPa}$ (Figure 2). The UHS Scheimpflug camera has blue light LED (455 nm, UV free) and covers $8.5 \mathrm{~mm}$ horizontally of a single slit. Recording measurement time is $30 \mathrm{~ms}$, which allows for acquiring 140 digital frames. Each image has 576 measuring points.

This imaging system allows dynamic inspection of the actual deformation process during NCT. Advanced algorithms for edge detection of the corneal contours are applied for every frame (Figure 3). The recording starts with the cornea at the natural convex shape. The air puff forces the cornea inwards (ingoing phase) through applanation (first or ingoing applanation) into a concavity phase until it achieves the highest concavity (HC). There is an oscillation period before the outgoing or returning phase. The cornea undergoes a second applanation before achieving its natural shape when there is a possible oscillation.

The timing and corresponding pressure of the air puff at

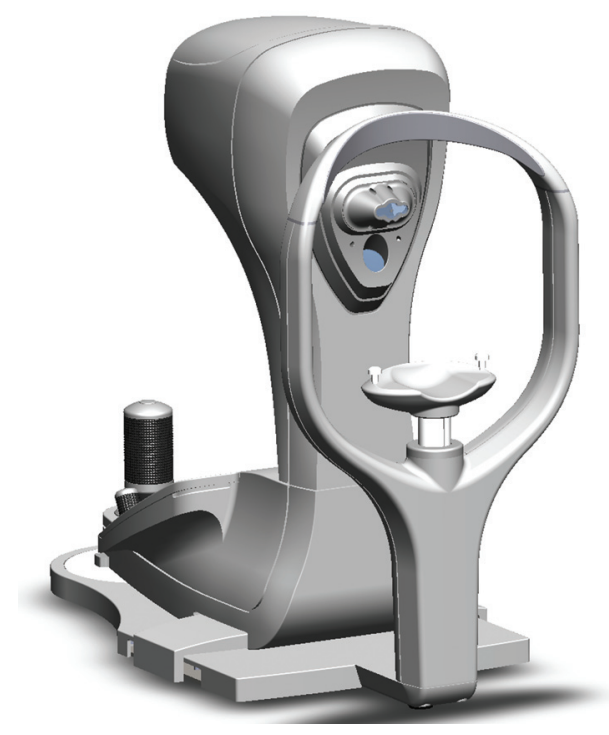

Figure 1: Oculus Corvis ST (Wetzlar, Germany)

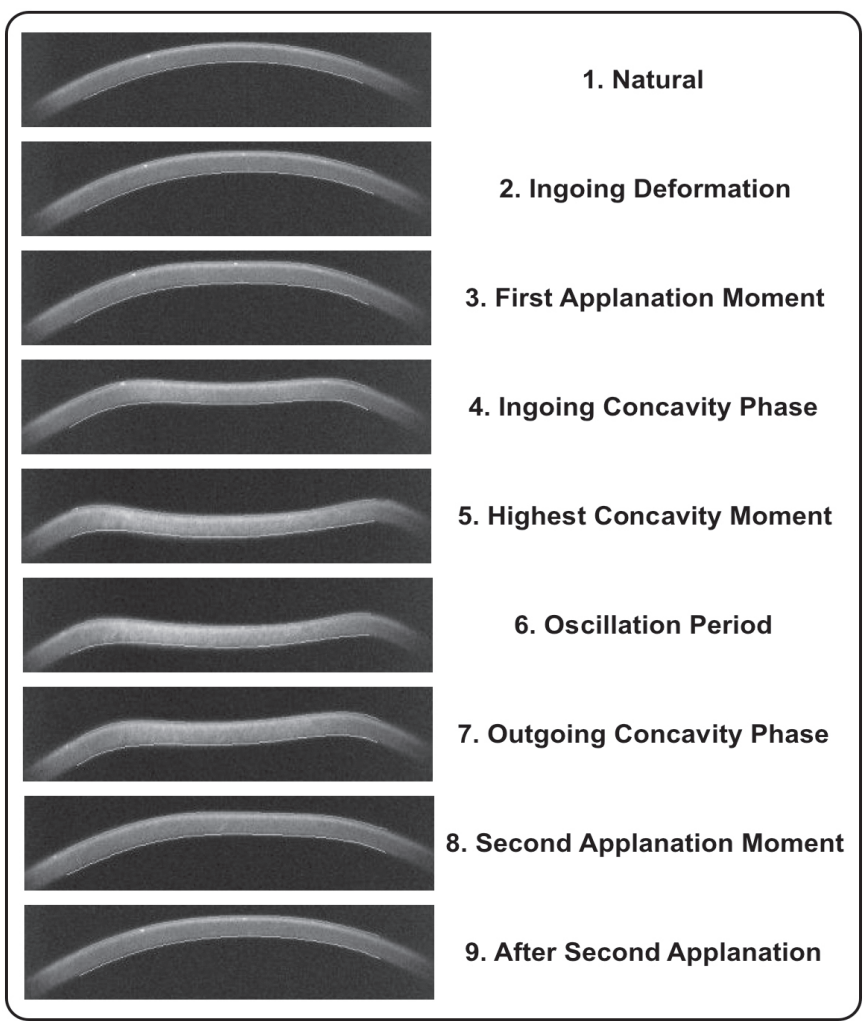

Figure 2: Graphic presentation of the air pressure (internal) and the corneal apex signal with detected applanation moments

the first and second applanations and at the $\mathrm{HC}$ moments are identified. Intraocular pressure (IOP) is calculated based on the timing of the first applanation event. This initial IOP measurement is dependant of corneal resistance. The deformation amplitude (DA) is detected as the highest displacement of the apex in the $\mathrm{HC}$ moment image. The radius of curvature at highest concavity is recorded. Applanation lengths 

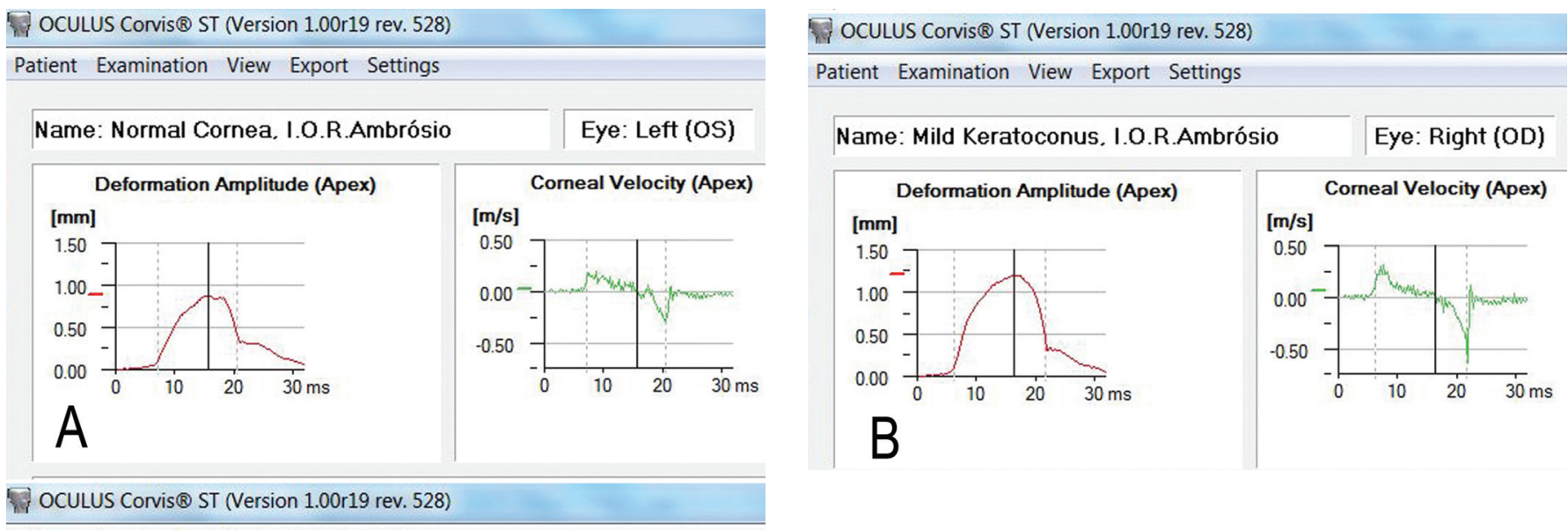

Figure 3: Selected Scheimpflug image frames of a normal cornea during the measurement

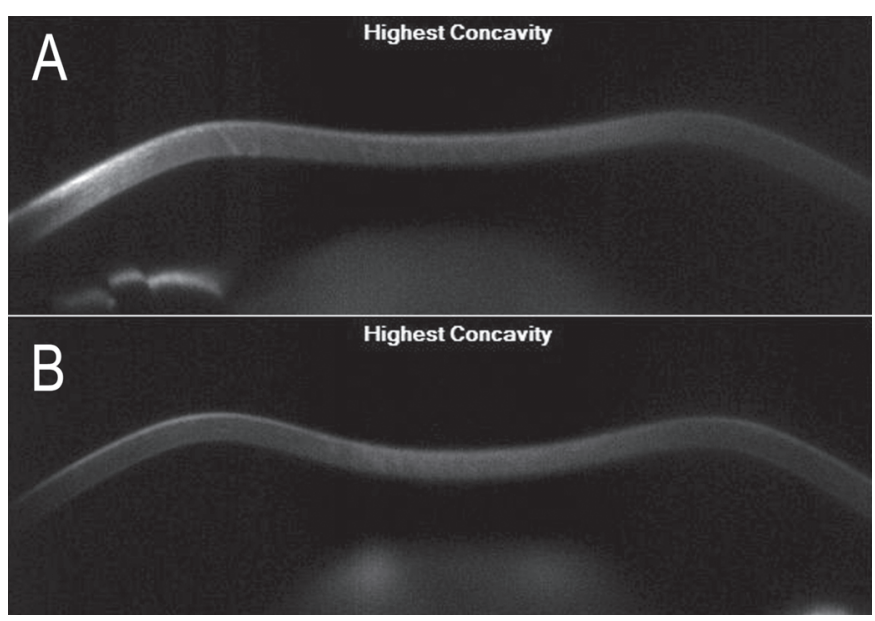

Figure 4: Graphic display report of a normal thin (A) and mild keratoconic cornea; (B) with the deformation amplitude and corneal velocity plots versus time

(AL) and corneal velocities (CVel) are recorded during ingoing and outgoing phases. Corneal thickness is also calculated through the horizontal Scheimpflug image. The lowest value is displayed.

\section{ResUlts}

Figures 3 and 4 summarize the Corvis ST findings in a normal thin cornea (Figures $3 \mathrm{~A}$ and $4 \mathrm{~A}$ ), compared to one with mild keratoconus (Figures 3B and 4B). Both corneas have relatively similar central corneal thickness of $500 \mu \mathrm{m}$ and similar IOP of $14 \mathrm{mmHg}$. The deformation of the ectatic cornea is more pronounced, having higher DA and corneal velocities. The applanation lengths in the ectatic cornea are smaller.

Such parameters have been found useful for the diagnosis of ectasia (2), as well as for assessing CXL results (Roberts, unpublished data 2011). In the FDA trial of corneal collagen crosslinking conducted at The Ohio State University, subjects were evaluated biomechanically using the Corvis ST before and after the procedure. 11 keratoconic subjects randomly selected for the treatment group, were compared with 8 keratoconic subjects randomly selected to be in the sham group. At one month post-procedure, a significant difference $(\mathrm{p}<0.0014)$ was found in the radius of curvature at highest concavity in those subjects who received treatment, consistent with increased stiffness. Subjects in the sham group showed no difference $(\mathrm{p}=0.6981)$ at one month. Greater negative magnitude in the radius of curvature after corneal collagen crosslinking or a flatter curvature at maximum deformation was observed.

\section{Discussion}

We have described a new technique for the non-invasive imaging of the dynamic response of the cornea to an air puff during NCT, using UHS Scheimpflug imaging. The inspection of the corneal slit during the deformation allows for objective and subjective analysis. The different corneal responses to the same deformation stimuli obtained with the normal thin and mild keratoconic cornea indicate that there are significant differences in biomechanical properties despite these corneas having similar thickness. The relative contribution of intraocular pressure in the measurement is relatively eliminated in the example, as both eyes have similar IOP. In addition, the ability to evaluate the deformation response has the potential for demonstrating clinical evidence for biomechanically evaluating the effect of collagen crosslinking procedure. ${ }^{20}$

The retrieved data and deformation obtained by the Corvis ST provide information related to the biomechanical properties of the tissue, including elasticity and viscoelasticity. Very importantly, the deformation data may allow for more precise intraocular pressure measurements, which is also a significant influent of the deformation response. Therefore, the ultimate goal to understand the biomechanical properties of the corneal tissue and to measure IOP will have to be achieved together.

The generated parameters can be integrated using linear and/or more advanced artificial intelligence algorithms for improving the accuracy of detecting disease and the impact of surgery. These parameters can be also used in combination with corneal tomography and ocular biometry data.

The integration of ultra-high-speed Scheimpflug imaging with NCT has an enormous potential as a research and clinical tool to retrieve in vivo biomechanical properties of the cornea. These measurements could be considered in finite element models that would improve diagnosis and prognosis of corneal diseases and improve safety and efficacy of corneal surgery. 


\section{ReFERENCES}

1. Salomao MQ,Esposito A, Dupps WJ,Jr.Advances in anterior segment imaging and analysis. Curr Opin Ophthalmol. 2009;20(4):324-32.

2. Ambrosio R, Jr., Nogueira LP, Caldas DL, Fontes BM, Luz A, Cazal $\mathrm{JO}$, et al. Evaluation of corneal shape and biomechanics before LASIK. Int Ophthalmol Clin. 2011;51(2):11-38.

3. Dupps WJ, Jr., Wilson SE. Biomechanics and wound healing in the cornea. Exp Eye Res. 2006;83(4):709-20.

4. Andreassen TT, Simonsen AH, Oxlund H. Biomechanical properties of keratoconus and normal corneas. Exp Eye Res. 1980;31(4):435-41.

5. Roberts C. Biomechanical customization: the next generation of laser refractive surgery. J Cataract Refract Surg. 2005;31(1):2-5.

6. Liu J, Roberts CJ. Influence of corneal biomechanical properties on intraocular pressure measurement: quantitative analysis. J Cataract Refract Surg. 2005;31(1):146-55.

7. Congdon NG, Broman AT, Bandeen-Roche K, Grover D, Quigley HA. Central corneal thickness and corneal hysteresis associated with glaucoma damage. Am J Ophthalmol. 2006;141(5):868-75.

8. Kotecha A. What biomechanical properties of the cornea are relevant for the clinician? Surv Ophthalmol. 2007;52 Suppl 2:S109-14.

9. Brown KE, Congdon NG. Corneal structure and biomechanics: impact on the diagnosis and management of glaucoma. Curr Opin Ophthalmol. 2006;17(4):338-43.

10. Elsheikh A, Geraghty B, Rama P, Campanelli M, Meek KM. Characterization of age-related variation in corneal biomechanical properties. J R Soc Interface. 2010;7(51):1475-85.

11. Dupps WJ, Jr. Biomechanical modeling of corneal ectasia. J Refract Surg. 2005;21(2):186-90.

12. Carvalho LA, Prado M, Cunha RH, Costa Neto A, Paranhos A, Jr., Schor P, et al. Keratoconus prediction using a finite element model of the cornea with local biomechanical properties. Arq Bras Oftalmol. 2009;72(2):139-45
13. Luce DA. Determining in vivo biomechanical properties of the cornea with an ocular response analyzer. J Cataract Refract Surg. 2005;31(1):156-62.

14. Knox Cartwright NE, Tyrer JR, Marshall J. Age-related differences in the elasticity of the human cornea. Invest Ophthalmol Vis Sci. 2011;52(7):4324-9.

15. Jaycock PD, Lobo L, Ibrahim J, Tyrer J, Marshall J. Interferometric technique to measure biomechanical changes in the cornea induced by refractive surgery. J Cataract Refract Surg. 2005;31(1):175-84.

16. Scarcelli G, Pineda R, Yun SH. Brillouin optical microscopy for corneal biomechanics. Invest Ophthalmol Vis Sci. 2012;53(1):185-90.

17. Dorronsoro C, Pascual D, Perez-Merino P, Kling S, Marcos S. Dynamic OCT measurement of corneal deformation by an air puff in normal and cross-linked corneas. Biomed Opt Express. 2012;3(3):473-87.

18. Grabner G,Eilmsteiner R, Steindl C,Ruckhofer J,Mattioli R,Husinsky W. Dynamic corneal imaging. J Cataract Refract Surg. 2005;31(1):163-74.

19. Bonatti JA, Bechara SJ, Carricondo PC, Kara-Jose N. Proposal for a new approach to corneal biomechanics: dynamic corneal topography. Arq Bras Oftalmol. 2009;72(2):264-7.

20. Ambrósio Jr R. Evidência Biomecânica do Crosslinking $(\mathrm{CxL})$. Ectasia de Córnea com Fotografia de Scheimpflug em altíssima velocidade. Oftalmologia em Foco. 2012; 138: 31-32

\section{Corresponding Author:}

Renato Ambrósio Jr, MD, PhD

Rua Conde de Bonfim, n $^{\circ}$ 211/712 - Tijuca

CEP 20520-050 - Rio de Janeiro (RJ), Brazil

email:dr.renatoambrosio@gmail.com 